\title{
"Nós passamos por uns maus bocados": análise das narrativas dos serv(i)dores públicos federais sobre o trabalhar
}

\author{
Thaís Moura Monteiro ${ }^{1}$ \\ Centro Universitário Luterano de Palmas (Palmas, TO, Brasil) \\ Liliam Deisy Ghizoni ${ }^{2}$ \\ Universidade Federal do Tocantins (Palmas, TO, Brasil) \\ Thayanne Karoline Abreu e Silva ${ }^{3}$ \\ Sistema de Crédito Cooperativo (Palmas, TO, Brasil) \\ Geovanna Gomes de Morais ${ }^{4}$ \\ Clínica privada (Palmas, TO, Brasil)
}

\begin{abstract}
Este artigo apresenta os resultados de uma escuta clínica do sofrimento no trabalho com um grupo de servidores públicos federais. O aporte teórico é da Psicodinâmica do Trabalho e o percurso metodológico centra-se na construção de um espaço de discussão proposto pela prática clínica, com uso dos seguintes dispositivos: análise da demanda, transferência e interpretação; formação do clínico e supervisão clínica. Objetiva-se analisar as narrativas dos participantes por meio de uma pesquisa qualitativa de caráter descritivo. Foram realizadas 12 sessões com a participação de 11 servidores. Conclui-se que o uso dos dispositivos clínicos permitiu que os serv(i)dores mudassem suas atitudes frente ao trabalho, visto que atribuíram novos sentidos ao trabalho, (re) significando, assim, os conteúdos que desencadearam sofrimento intenso. Desse modo, percebeu-se que houve uma reorganização do sistema defensivo. Confirma-se, assim, a importância da clínica como potencial político de organização coletiva.
\end{abstract}

Palavras-chave: Psicodinâmica do trabalho, Sofrimento, Servidor público.

"We've gone through some hard time": analysis of the narratives of federal public servants about working

This article presents the results of clinical listening to suffering at work with a group of federal civil servants. The theoretical contribution comes from Psychodynamics of Work and the methodological approach focuses on the construction of a space for discussion as proposed by clinical practice, using the following devices: demand analysis, transference and interpretation; clinician training and clinical supervision. The objective is to analyze the participants' narratives through qualitative research and descriptive perspective. Twelve sessions were held with the participation of eleven civil servants. It is concluded that the use of clinical devices allowed civil servants to change their attitudes towards work, as they attributed new meanings to work, thus (re) signifying the contents that triggered intense suffering. Thus, it was noticed that there was a reorganization of the defensive system, and the importance of the clinic as a political potential for collective organization is confirmed.

Keywords: Psychodynamics of work, Suffering, Public servant.

https://orcid.org/0000-0002-3155-4765

2 https://orcid.org/0000-0002-1254-7455

3 https://orcid.org/0000-0003-1943-0767

4 https://orcid.org/0000-0002-6472-4994 


\section{Introdução}

Z ste artigo é fruto de uma pesquisa de mestrado e tem por objetivo analisar as narrativas de Eum grupo de serv(i)dores públicos federais ${ }^{5}$ a partir do uso dos dispositivos da escuta clínica do sofrimento no trabalho. Trata-se de um estudo que integra as ações do Grupo de Pesquisa Trabalho e Emancipação: Coletivo de Pesquisa e Extensão. Contou-se com a parceria do Subsistema Integrado à Saúde do Servidor (SIASS) para indicar uma instituição federal que tivesse a demanda por uma escuta clínica, tendo em vista que o órgão recebe diariamente casos que necessitam de uma atenção voltada para a saúde mental do serv(i)dor público federal.

Diante da demanda, iniciou-se o processo em junho de 2017 junto ao SIASS, depois diretamente com o órgão federal e concluiu-se um ano após. Destarte, neste artigo, descreve-se o movimento do grupo ao longo do processo, entre contato inicial, sessões, discussão do relatório e avaliação da escuta clínica.

Nesta pesquisa, opta-se por utilizar a escrita "serv(i)dor" a fim de suscitar o sentido dual da palavra, bem como traçar possíveis reflexões sobre a temática. Elaborou-se, ainda, uma fórmula personalizada desse termo para ilustrar os significados adotados nesta pesquisa (Figura 1). A representação a seguir é também um convite ao leitor para conhecer uma narrativa que se propõe a contar uma história de um grupo de serv(i)dores públicos federais que vivenciaram situações de sofrimento intenso no contexto laboral.

Figura 1: Significado da expressão serv(i) dor

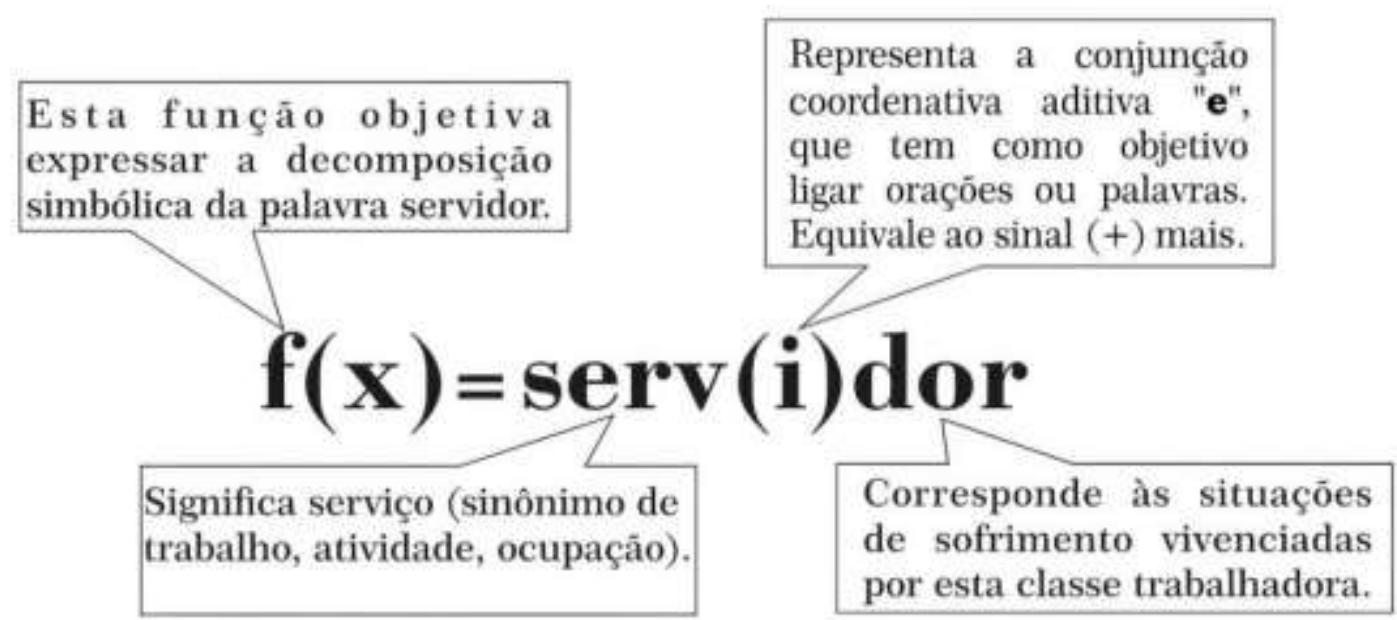

Fonte: Monteiro, 2018

As relações de trabalho no âmbito público encontram-se regidas sob normas e prescrições, as quais atendem aos atuais modelos de gestão que utilizam práticas intensificadas de controle. Observa-se também a falácia da "estabilidade" que esconde muitas dores dessa categoria. Paulatinamente, as características do setor privado têm deslizado para o contexto público, desencadeando a supervalorização das tarefas, deixando as pessoas à mercê da precarização do trabalho. Esse novo modelo de gestão pública tem dificultado a criação de espaços de discussão e, sobretudo, o exercício da criatividade (Siqueira \& Mendes, 2009).

Nos estudos realizados por França (1993) e Ferri (2003), foi possível identificar a imagem associada ao serv(i)dor público, o qual carrega consigo um conjunto de estereótipos historicamente construídos. Faz-se alusão ao sujeito que não trabalha, tecendo diversas características, tais como: ineficiente, incapaz, desanimado, improdutivo, acomodado, faltoso, lento e que não atende com qualidade.

5 Não foi autorizada a divulgação do nome da instituição pública federal onde estes serv(i)dores trabalham, a fim de resguardar e garantir que as informações cedidas não serão utilizadas em prejuízo da imagem da organização. 
Dessa forma, o símbolo atribuído ao trabalho tem impactado a relação que os serv(i)dores estabelecem com os processos de trabalho na esfera pública, sendo a subjetividade e a identidade desses trabalhadores construídas a todo instante, constituindo-se na efemeridade dos processos organizacionais de trabalho. Ora sentem prazer, ora sofrem. Nas palavras de Mendes e Ghizoni (2016, p. 3), "sofrer no trabalho é um modo de manter vivo o sujeito no e do trabalho, embora também seja esta mesma força, que mortifica o sujeito quando o sofrimento é gozo e escapa à ética do desejo".

Diante desse cenário, emergiu a necessidade de ilustrar nesta pesquisa a figura do serv(i)dor público, tendo como inspiração as discussões propostas por França (1993) e Ferri (2003); destarte nasceu a charge ${ }^{6}$ a seguir.

Figura 2: Imagem associada ao serv(i)dor público Adriano Alves (junho, 2018)

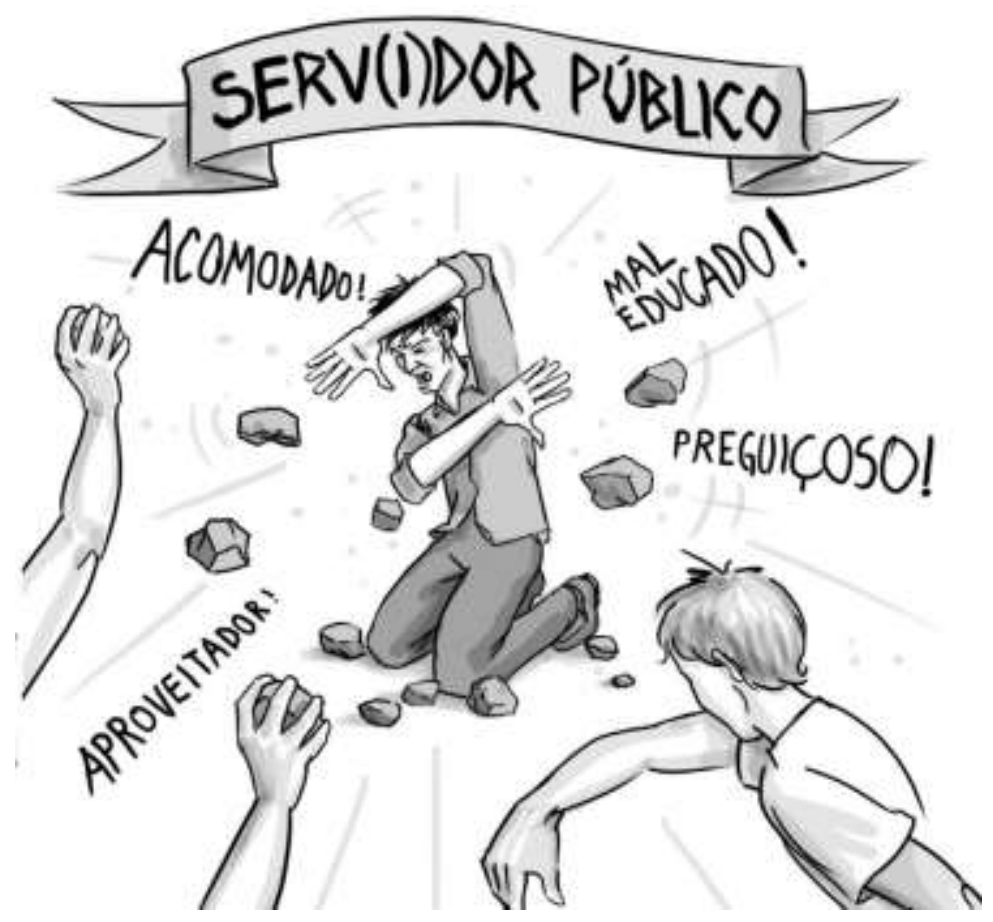

Fonte: Monteiro (2018).

Foi possível observar que a dimensão subjetiva do trabalho dos serv(i)dores públicos propiciou o entendimento do significado e do sentido dessa atividade que, aos olhos dos que não a vivenciam, são verbalizados como algo muito positivo. Os altos salários e a "promessa" da estabilidade são aspectos que justificam esses discursos, porém, os que estão inseridos nos processos organizacionais vivenciam as consequências das metamorfoses do setor público. A mudança do estilo de gestão, a busca por produtividade, a falta de recursos e de reconhecimento são características dessa nova organização do trabalho.

As condições de trabalho do serv(i)dor público catalisam os sofrimentos advindos do trabalhar, os quais originam-se de como é estabelecida a organização do trabalho (SeligmannSilva, 2011). De acordo com Dejours (2004, p. 30), "trabalhar constitui, para a subjetividade, uma provação que a transforma. Trabalhar não é somente produzir; é, também, transformar a si mesmo e, no melhor dos casos, é uma ocasião oferecida à subjetividade para se testar, até mesmo para se realizar".

É com essa visão do pai da Psicodinâmica do Trabalho que se olha para as narrativas dos serv(i)dores participantes desta prática clínica. A Psicodinâmica do Trabalho (PdT) reverbera um olhar para as relações de trabalho do sujeito e do sofrimento psíquico, em busca da saúde

6 Charge feita exclusivamente para a dissertação da primeira autora, pelo artista Adriano Alves @ adrians10 (junho, 2018). 
mental a partir dos processos de subjetivação e prazer (Gama et al., 2016; Lhuilier, 2011). Essa abordagem científica (PdT) ficou conhecida no Brasil a partir do lançamento do livro A loucura do trabalho, em 1987, desenvolvido por Christophe Dejours, diretor, membro e professor do Laboratoire de Psychologie de Conservatoire National des Artes et Métiers (CNAM) de Paris.

O referido autor teceu novas formas de pensar a organização do trabalho, considerando o trabalho como um dispositivo central e potente para refletir na saúde psíquica do trabalhador, seja como fonte de prazer ou alvo de adoecimentos dos sujeitos que se encontram, por vezes, em condições deletérias. Para entender melhor a subjetividade do sujeito no contexto laboral, a abordagem PdT apropria-se de quatro campos do saber: a Psicologia, a Psicanálise, a Teoria Social e a Ergonomia. Portanto, buscam-se intervenções a partir das análises da organização do trabalho, a fim de delinear estratégias pautadas no coletivo (Dejours, 2004; Mendes, 2007).

Desse modo, neste estudo a prática clínica foi realizada em um órgão público federal, situado em Palmas - TO, região norte do país; um estudo com características regionais, em que se buscaram soluções para um problema local, mas de abrangência nacional, pois o sofrimento e a violência no ambiente de trabalho são constantes em diversos espaços organizacionais.

Diante desse contexto, nesta pesquisa optou-se por realizar uma escuta clínica do sofrimento no trabalho, baseando-se nos pressupostos metodológicos de Mendes (2014), que são: dispositivos para a escuta clínica (análise da demanda, transferência e interpretação); a formação do clínico e a supervisão clínica. A escuta clínica busca constituir um espaço de discussão para que haja a circulação da fala e dos afetos, possibilitando, assim, (re)pensar as práticas visíveis e invisíveis da organização do trabalho.

Nessa direção, a pergunta que norteia este artigo é: Quais narrativas os serv(i)dores públicos federais passam a ter com o uso dos dispositivos da escuta clínica do sofrimento no trabalho em Palmas.

\section{A escuta clínica do sofrimento no trabalho}

O método proposto por Mendes e Araujo (2012) na obra "Clínica Psicodinâmica do Trabalho: o sujeito em ação", reformulado por Mendes, em 2014, no livro "Trabalho \& Sofrimento: práticas clínicas e políticas", é o ponto que apresenta maior distinção entre a Psicodinâmica do Trabalho proposta por Dejours, com a produção científica que tem sido desenvolvida no centro-oeste do país. Nessa região do Brasil, alguns estudos têm se embasado nos novos delineamentos propostos por Ana Magnólia Mendes, professora, pesquisadora da UnB e autora de livros que envolvem a grande área do trabalho (Facas et al., 2017).

Esses autores fizeram uma distinção do perfil dos pesquisadores brasileiros, classificandoos em três categorias: "os que admiram a abordagem, os que divulgam e a reproduzem e os que criam e produzem conhecimento" (Facas et al., 2017, p. 15).

Mendes está inserida na categoria que cria e produz conhecimento, visto que, na sua nova proposta, sugere o papel do clínico-pesquisador, incluindo elementos psicanalíticos para a condução clínica. Além disso, a supramencionada autora destaca a importância da interpretação e da subjetividade do clínico, como aquele que se afeta com o sofrimento do outro, propiciando a circulação da palavra, dos afetos, dos silêncios, dando novos destinos ao sofrimento.

Périlleux e Mendes (2015) acreditam que a posição de ouvir o sujeito, entender os eventos traumáticos narrados, bem como desbanalizar as violências do trabalho e denunciar aquilo que não é "normal" são características fundamentais do clínico do trabalho. Todavia, fazse importante discutir as práticas clínicas, a fim de desvelar a política dos sintomas e o lugar que esse clínico do trabalho ocupa. Conforme esses autores, é um desafio não tratar um sintoma como problema e esperar uma solução, mas, sobretudo, vê-lo como um enigma que necessita, inexoravelmente, de uma decisão.

É por meio da palavra que o dispositivo clínico habita, revelando o evento do sintoma. É interessante enfatizar que a palavra enquanto linguagem é crucial para que o trabalho seja entendido e ressignificado pelo sujeito. Portanto, pensar em espaços de discussão requer a 
participação de um clínico-pesquisador, detentor de afetos e de um saber-fazer singular em decorrência da condução clínica, diferentemente de como agiria o pesquisador-clínico. O clínico do trabalho apropria-se de dispositivos potentes, tais como: a transferência, a interpretação, a formação do clínico e a supervisão clínica, as quais serão apresentadas e discutidas no método deste estudo.

Diante do exposto, vale descrever que os serv(i)dores participantes desta pesquisa atribuíram um nome ao grupo, denominando-o de "Grupo Fala-Escuta". Esta apropriação e identificação desvela o saber-fazer do coletivo para, juntos, desempenharem ações sobre o trabalho. Dessa forma, o nome do grupo, também trazido em algumas narrativas, no decorrer deste estudo, refere-se à escuta clínica do sofrimento do trabalho, delineada nos estudos de Mendes (2014).

\section{Método}

A natureza desta pesquisa é qualitativa, pois não reduz seus estudos a simples variáveis, posto que compreende o fenômeno em sua totalidade, considerando a complexidade e os contextos cotidianos nos quais os sujeitos estão inseridos (Flick, 2009).

A subjetividade da pesquisadora e dos participantes fizeram parte do processo de pesquisa e, conforme destacou Flick (2009), a pesquisa qualitativa proporciona que haja uma implicação tanto dos sujeitos pesquisados quanto do próprio pesquisador. Neste estudo, as reflexões e análises das clínicas-pesquisadoras foram documentadas via diários de campo, construídos após cada sessão.

Nesse sentido, foi criado um espaço de discussão na própria sede da instituição pública federal em Palmas, que se reunia semanalmente, para falar sobre o trabalho, mas com o objetivo de reverberar nos sujeitos a circulação de laços e afetos (Mendes, 2014). As narrativas produzidas nessas sessões é que foram o objeto de análise.

Para Périlleux (2013), o material constituído nas sessões é algo provisório, uma ficção que não pertence a nenhum dos participantes do grupo de forma particular, não podendo, portanto, ser generalizado.

Logo, o objetivo metodológico deste estudo foi descritivo (Gerhardt \& Silveira, 2009; Silva \& Menezes, 2001; Triviños, 1987), pois buscou-se relatar os fenômenos envolvidos no contexto de trabalho dos serv(i)dores públicos federais a partir de suas narrativas.

\section{Participantes}

Participaram desta prática clínica 11 serv(i)dores públicos federais, sendo 7 homens e 4 mulheres. A idade dos participantes variou entre 20 e 60 anos. O nível de escolaridade que prevaleceu foi a pós-graduação (7 pessoas), seguido do ensino superior incompleto ( 2 pessoas), ensino superior completo ( 1 pessoa) e ensino médio (1 pessoa). No que tange ao quadro de serv(i)dores públicos federais, tem-se: 6 técnicos, 4 analistas e 1 temporário. Ocupam as seguintes funções: gerência (1), supervisão (5), administrativo (4) e temporário (1). Sobre o tempo de serviço, constatou-se que $3 \operatorname{serv}(i)$ dores possuem menos de 5 anos na instituição, 6 possuem de 6 a 15 anos e 2 possuem mais de 16 anos de trabalho.

\section{Instrumentos}

Os instrumentos utilizados na escuta clínica do sofrimento no trabalho foram pautados na proposta metodológica de Mendes (2014), sendo que diversos autores já fizeram uso em suas escutas clínicas (Alves, 2014; Amaral, 2018; Duarte, 2014; Ghizoni, 2013; Ghizoni \& Mendes, 2014). Destarte, adotaram-se neste estudo os seguintes instrumentos: 
1. Gravação com a devida autorização dos participantes e transcrições das sessões: a clínica-pesquisadora responsável encaminhava os conteúdos para uma empresa de transcrição terceirizada, a qual se comprometia a entregar o material transcrito em até 72 horas;

2. Diário de campo: logo após o final de cada sessão, a clínica-pesquisadora e a estagiáriapesquisadora construíam seus respectivos diários, para que fosse possível transpor para o papel, ainda no calor da emoção, as vivências da sessão;

3. Quadro síntese da sessão: formulado por Amaral (2018) e adaptado para este estudo, por possibilitar a organização dos conteúdos da sessão, facilitando a dinâmica e o processo de análise das narrativas;

4. Memorial: onde são registrados os conteúdos mais importantes da sessão, os quais são levados para a validação do grupo na sessão posterior. Neste estudo, o memorial foi tomando forma, saindo de um campo mais estruturado (com interpretações), perpassando para um campo metafórico, subjetivo e de enfrentamento e, por último, deslizou para um campo mais poético;

5. Questionário para Levantamento de Perfil dos Serv(i)dores Públicos Federais: instrumento aplicado no final da $11^{\mathrm{a}}$ sessão.

\section{Procedimentos e cuidados éticos}

Por meio da parceria entre o Grupo de Pesquisa Trabalho e Emancipação: Coletivo de Pesquisa e Extensão e o Subsistema Integrado à Saúde do Servidor (SIASS), recebeu-se a indicação de uma instituição federal que estava com a demanda de uma escuta clínica em grupo.

Mediante a autorização da instituição responsável, indicada pelo SIASS, uma reuniãoconvite foi agendada para o dia 23 de agosto de 2017, a fim de convidar os serv(i)dores públicos federais a participarem da pesquisa. Desse momento, participaram a clínica-pesquisadora e a supervisora/orientadora. Nessa ocasião, foram explicados, aos participantes, os objetivos, os riscos e benefícios da pesquisa, assim como foram entregues duas vias do Termo de Consentimento Livre e Esclarecido (TCLE) para cada servidor, convidando-os a participarem da pesquisa de forma voluntária. Foi oportuno explanar, ainda, sobre a importância e os possíveis efeitos do processo de escuta clínica do sofrimento no trabalho (palestra de sensibilização ocorrida dia 23 de agosto de 2017).

Os serv(i)dores que concordaram em participar da pesquisa assinaram os TCLEs e ficaram com uma das vias, sendo a outra destinada à clínica-pesquisadora; os que não concordaram, devolveram os dois TCLEs em branco. Em seguida, agendou-se a primeira sessão para o dia 5 de setembro de 2017, com os sujeitos que tiveram interesse em participar da pesquisa. A duração de cada sessão foi em torno de noventa minutos, todas gravadas (áudio) e transcritas posteriormente. Ao total, foram realizadas doze sessões, uma vez por semana, conforme sugeriram Mendes e Araujo (2012), bem como foi sinalizado pelo andamento do próprio grupo. A última sessão ocorreu dia 21 de novembro de 2017.

Praticamente dois meses após a última sessão, ocorreu a reunião de devolutiva dos resultados (30 de janeiro de 2018). Na ocasião, o relatório final da pesquisa foi apresentado ao grupo para validação. Sete serv(i)dores, a clínica-pesquisadora, a estagiária-pesquisadora e a professora supervisora do estudo participaram da discussão do relatório, momento aberto para que os serv(i)dores pudessem opinar sobre os conteúdos trazidos pelo coletivo de clínicaspesquisadoras e construir possiblidades de caminhar enquanto grupo, sem a interferência das clínicas-pesquisadoras, que se despediam naquele momento.

No dia 26 de junho de 2018, um período de sete meses após o término das sessões, o coletivo de clínicas-pesquisadoras retornou à instituição para fazer uma avaliação do grupo. $\mathrm{O}$ propósito do encontro foi observar como estava acontecendo a mobilização subjetiva dos participantes e quais estratégias estavam utilizando após ter passado por um espaço de discussão sobre os prazeres e os sofrimentos decorrentes do contexto de trabalho. 


\section{Análise dos Dados}

A estratégia de análise dos dados foi baseada na Análise Clínica do Trabalho que, de acordo com Mendes e Araujo (2012), é uma técnica que propõe organizar os materiais levantados nas sessões (por sessão e na sua totalidade), fundamentando-se nos significados emergidos nas narrativas. Entretanto, baseou-se, também, na reestruturação metodológica proposta por Mendes (2014), que definiu como eixos estruturantes do método: I. os dispositivos para a escuta clínica do sofrimento, quais sejam: (a) análise da demanda, que pode surgir tanto de um trabalhador, do coletivo de trabalhadores, de uma instituição ou, ainda, de pesquisadores que estudam a temática; (b) a transferência, que possibilita a circulação do afeto e a reverberação de um espaço de falaescuta. Na clínica do sofrimento no trabalho, a transferência ocorre quando os participantes não se submetem a uma postura de onipotência e situações de sedução, mas admitem o que se passa com eles (queixas, sintomas e desejos); (c) a interpretação, que consiste na análise do sofrimento decorrente do contexto de trabalho. Trata-se, portanto, de uma análise baseada nas interpretações das narrativas de cada sessão da prática clínica; II. a formação do clínico, a qual envolve a qualificação teórica, a prática clínica, bem como a análise pessoal do clínicopesquisador; III. a supervisão clínica, que neste estudo foi com a orientadora da pesquisa.

\section{Resultados}

A constituição do Grupo Fala-Escuta reverberou narrativas sobre o trabalho dos serv(i)dores públicos federais em suas múltiplas instâncias (prazer, sofrimento, violência no trabalho etc.). A imposição do real do trabalho obteve destaque nas sessões.

A instituição pública federal à qual os participantes deste estudo estavam vinculados vivenciou situações de violência no trabalho por um período de aproximadamente quatro anos, expressa por agressões verbais (gritos, xingamentos e palavras com tons grosseiros) e por relações interpessoais conflitivas.

Vale destacar que se trata de uma categoria profissional bastante falada nos discursos da sociedade civil como sendo um objeto de desejo para muitos, porquanto traz possibilidades para se viver com a sonhada "estabilidade". Porém, essa classe passa por um contexto atual de precarização do trabalho e dos ritmos de trabalho. Traesel e Merlo (2014, p. 225) destacaram que "o serviço público tem sido lócus de conflitos e vivências de sofrimento relacionados a práticas perversas de gestão, competição, falta de reconhecimento, invisibilidade e assédio moral".

Acrescenta-se, ainda, que as políticas de gestão de pessoas, bem como os programas que vendem a qualidade de vida no trabalho, na maioria das vezes, são implementados nas instituições públicas de forma muito desconexa e descontextualizada, ao passo que não atendem a real necessidade dos serv(i)dores. Com a reforma gerencial, há um deslocamento das tecnologias de gestão do setor privado para o âmbito público, desconsiderando as idiossincrasias do trabalho e do próprio trabalhador.

Nas sessões, os serv(i)dores relataram detalhes sobre a relação com os pares e as chefias, assim como optaram por distinguir, nas narrativas, a gestão em três momentos: a gestão anterior, a gestão-tampão e a gestão atual.

\section{Resumo das sessões}

No primeiro momento, compreendido pelas sessões 1, 2 e 3, as narrativas tiveram foco na gestão anterior. 
Figura 3: Principais temas identificados nas sessões 1, 2 e 3

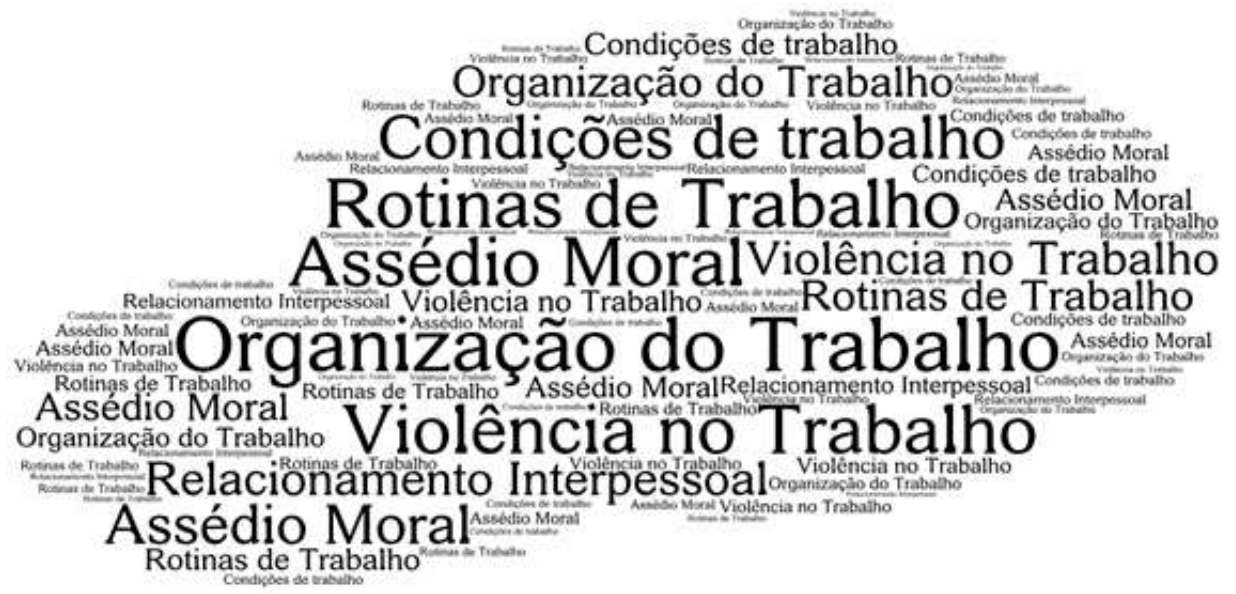

Fonte: Monteiro (2018).

Como se pode observar, as sessões iniciais centraram-se nas questões relacionadas à organização do trabalho (condições e rotinas de trabalho), bem como nas situações de violência no trabalho vivenciadas pelo grupo, sendo denominadas, pelo coletivo, de assédio moral, apesar de não ter sido reconhecido como tal nas instâncias jurídicas.

Na sequência, o segundo momento é composto pelas sessões 4, 5, 6, sendo caracterizado como um período de transição, ao passo que os participantes deixaram de focar somente no passado e começaram a trazer questões relacionadas à organização do trabalho atual.

Figura 4: Principais temas identificados nas sessões 4, 5 e 6

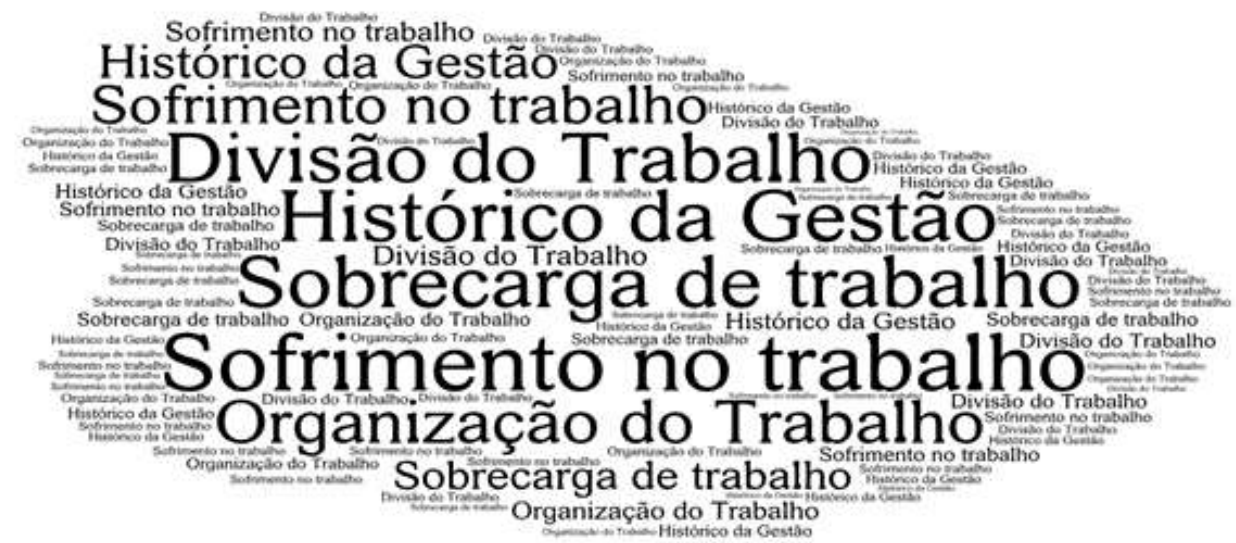

Fonte: Monteiro (2018)

A sobrecarga no trabalho foi um assunto amplamente discutido e, de acordo com os participantes, inerente ao momento atual. A divisão do trabalho, a organização do trabalho e o sofrimento no trabalho também foram temas recorrentes. Por caracterizar uma fase de transição, assim intitulada pela clínica-pesquisadora, o grupo sentiu a necessidade de narrar o histórico da gestão, subdividido por eles em três gestões.

Cabe pontuar que a demanda da sobrecarga no trabalho foi potencializada com as mensagens via WhatsApp:

Nós temos os grupos ... né? E a gente sempre tem que tá respondendo. E, às vezes, a gente não conseguiu ficar muito focado nas nossas discussões porque a gente também, quer queira ou quer não, não sei se inconscientemente, a gente tá muito ligado lá fora, né, a gente tá muito ligado nos trabalhos lá fora (Transcrição da 4⿳a Sessão, 26 set. 2017). 
Nessa perspectiva, o acúmulo de demandas advindas do meio eletrônico (e-mail e WhatsApp) foi narrado pelo grupo a partir de relatos de sofrimento no trabalho.

Só pra você ter uma ideia. Olha só o nível, a pessoa me liga, eu: [Nome da Instituição], boa tarde. No meu celular, entendeu. Falei, gente, olha a que ponto estamos (Transcrição da 4⿳亠丷厂 Sessão, 26 set. 2017)... trabalho com número o dia inteiro e respondo o pessoal no WhatsApp até dez horas da noite no trabalho (Transcrição da 4 a Sessão, 26 set. 2017). . . a demanda de trabalho urge, as coisas têm que ser assim, todo mundo na ponta da agulha, na ponta da agulha (Transcrição da $6^{\underline{a}}$ Sessão, 10 out. 2017).

Em virtude dessa intensificação dos ritmos de trabalho, os serv(i)dores afirmam, muitas vezes, não conseguir dar uma pausa. "Às vezes vocês me chamam pra lanchar, pra fazer alguma

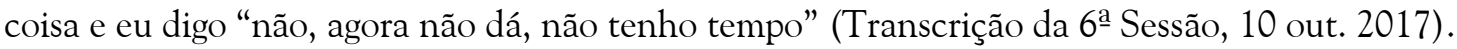

Assim, caracterizar essa sobrecarga de trabalho foi algo bastante trabalhado na supervisão clínica. A clínica-pesquisadora estava tendo dificuldade para desmontar o sistema defensivo do grupo (naturalização da dor, por exemplo), a fim de que se pudesse acessar o que de fato mobilizava os participantes. Com isso, a clínica-pesquisadora levou um memorial mais incisivo na condução da sessão subsequente, possibilitando contextos de confronto para desmontar as defesas coletivas. A partir de então, o coletivo deu início à mobilização subjetiva, enfrentando as defesas, elaborando e perlaborando os contextos de sofrimento, apropriando-se da metáfora trazida no memorial lido na 6⿳亠丷 sessão "Não basta ter a faca e o queijo na mão, é preciso ter fome".

Abrangendo as sessões 7, 8, 9 e 10, o terceiro momento ilustra o avanço do grupo, que buscou entender o prescrito (leis, editais e regimentos) para mudar o trabalho. Foi necessário revisitar esses materiais para que se pudesse prosseguir nas discussões sobre as atribuições dos técnicos e dos analistas, tema com intensa reverberação no grupo. Também foram discutidos os conteúdos do e-mail que o grupo se mobilizou para enviar ao gestor, fazendo com que esse terceiro momento se tornasse um canal de deliberações.

Figura 5: Principais temas identificados nas sessões 7, 8, 9 e 10

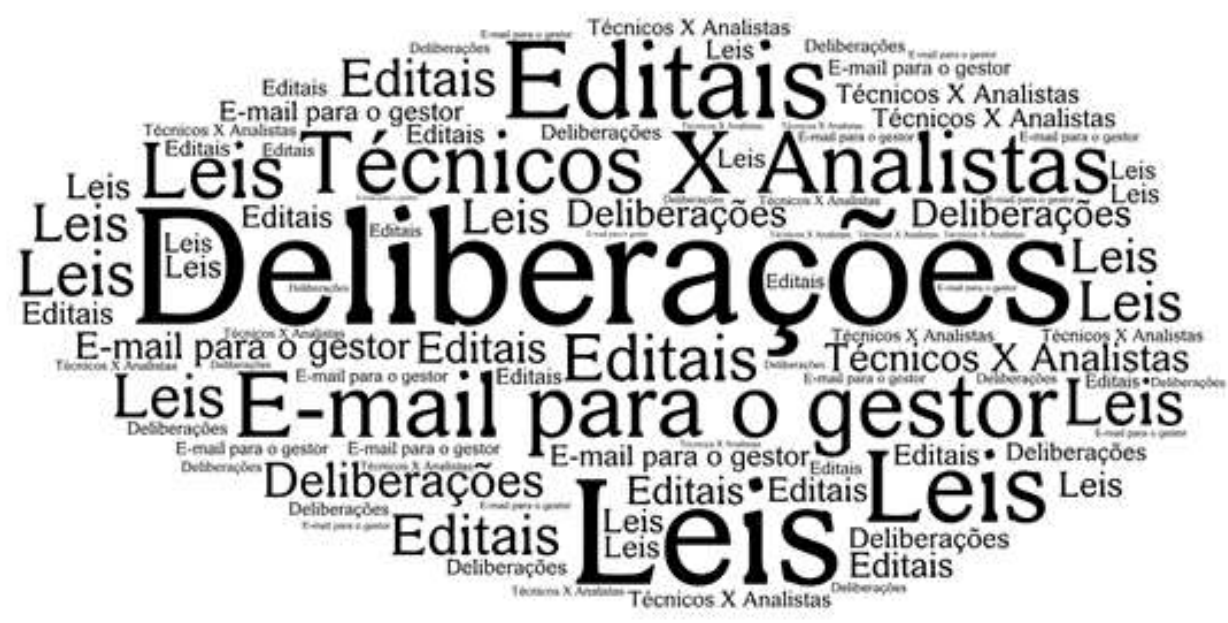

Fonte: Monteiro (2018).

O quarto momento envolve a sessão 11 (penúltima), ilustrada pela mobilização subjetiva, pelos avanços e pelas reflexões do processo clínico, conforme é possível visualizar a seguir. 
Figura 6: Temas centrais identificados na sessão 11

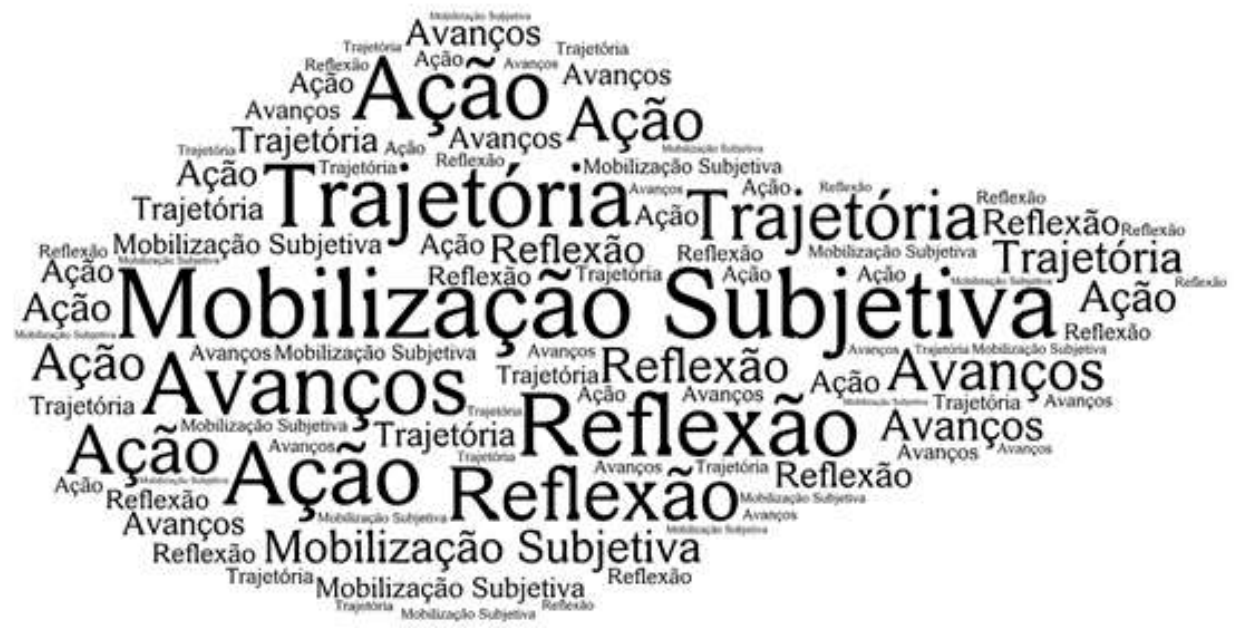

Fonte: Monteiro (2018)

Cabe acrescentar que, na penúltima sessão, após a leitura do memorial, o grupo reagiu verbalizando que acharam poético, elogiaram o conteúdo, alguns se identificaram, teve gente que se emocionou, confirmando assim que houve transferência e afetividade no grupo. Dessa forma, vê-se que este memorial objetivou narrar a trajetória que se construiu pelo coletivo de clínicas-pesquisadoras e serv(i)dores.

As resistências começaram a surgir quando perceberam que o memorial encaminhava para o fim da escuta clínica do sofrimento no trabalho. Em meio aos sistemas defensivos, a clínicapesquisadora envolveu o grupo para a tomada de decisão, resgatando o movimento do coletivo de serv(i)dores, conforme ilustrado na figura abaixo.

\section{Figura 7: Movimento do Grupo}

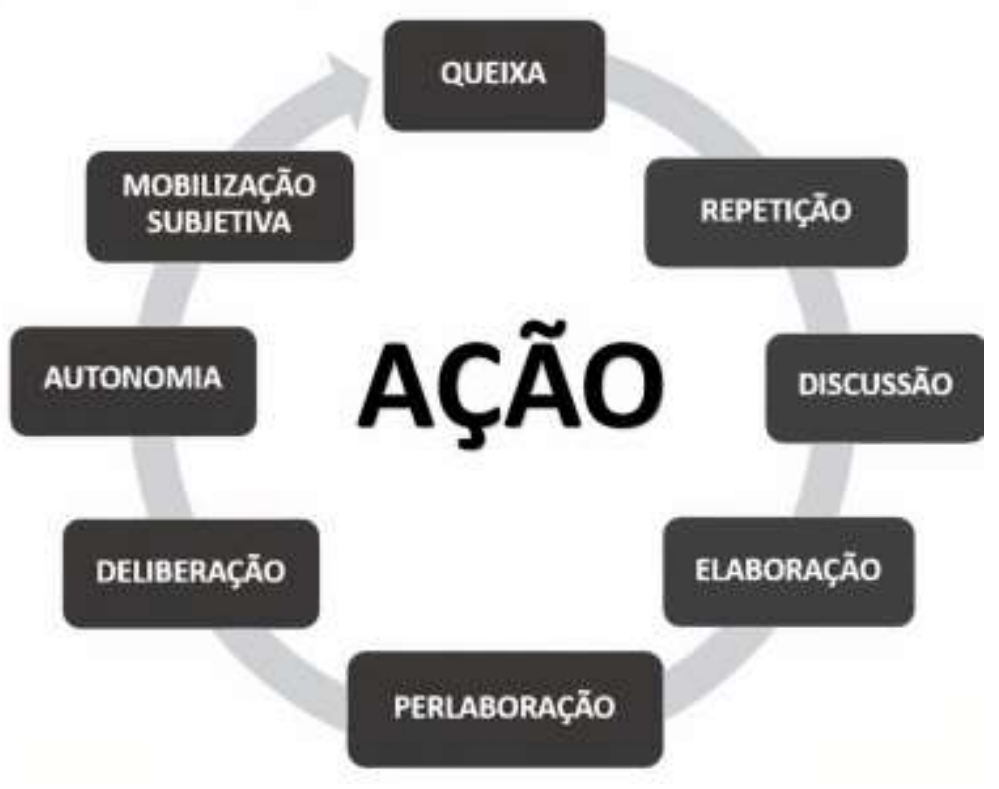

Fonte: Monteiro (2018).

Primeiro, ficaram na queixa e na repetição, depois foram acessando a dor com as discussões, elaborando, perlaborando, até darem início às deliberações, criando contextos de autonomia e mobilizando-se subjetivamente por meio da ação. Concomitantemente ao fim iminente da escuta clínica, emergiram manifestações de insegurança por parte do grupo, o que 
suscitou das clínicas-pesquisadoras uma análise sobre o que o grupo estava demandando. Na sequência, identificou-se que esses comportamentos estavam relacionados ao sentimento de aflição com a despedida que se aproximava.

Nesse aspecto, os trabalhadores começaram a dar depoimentos do quanto o processo de "fala-escuta" os ajudou. Uma servidora falou que gostou muito, inclusive dos memoriais, perguntou se não poderia tê-los, abriu-se para o grupo decidir. Acharam melhor não receber, pois em alguns memoriais havia nomes de uns serv(i)dores. Perguntaram, então, se podiam ter esse último, já que não eram citados nomes. A clínica-pesquisadora respondeu que sim e que levaria na próxima semana. Na semana seguinte, os memoriais foram entregues em formato de diploma (Figura 10), enrolados por uma fita, demarcando, assim, um símbolo para o grupo.

Nas narrativas, foi possível identificar uma valorização do processo de escuta clínica, dos espaços de discussões, das circulações de laços de cooperação, solidariedade e afetividade. Nessa sessão, o grupo demonstrou insegurança com relação ao fim do processo clínico. A clínicapesquisadora retomou o que já havia dito em alguns momentos durante a escuta clínica, afirmando que estava apenas de passagem e que já conseguia visualizar que eles estavam caminhando sozinhos. Uma servidora retomou esse "caminhar sozinho", comparando o grupo com uma bengala, reafirmando que ainda precisava desse apoio.

Um serv(i)dor fez outra pontuação:

Agora assim, eu acho o seguinte, eu sou um pouco mais ousado nesse sentido, acho que a gente já pode sim correr atrás, né. E, eu não sei quando a [cita o nome da clínica pesquisadora] pretende encerrar, se hoje ou só mais uma reunião, eu acho que seria bom pra gente já ficar mais focado na prática, a gente já falou, já conversou, então vamos botar em prática tudo que a gente tem pensado e aí depois no ano que vem a gente volta a se reunir uma vez por mês, continua falando, escutando, continuando essas deliberações. Eu acho que tá na hora da gente correr mais (Transcrição da 11르 Sessão, 14 nov. 2017).

Diante dessa fala, juntamente com o grupo, definiu-se que aconteceria mais uma sessão para a finalização do processo clínico.

O último momento, não menos importante, demarcou os avanços do grupo por meio de retrospectivas, bem como elaborações sobre o final desta escuta clínica. Foi possível visualizar o engajamento grupal, simbolizado pelo clima de confraternização. Os trabalhadores relembraram sobre os caminhos que percorreram ao longo do processo clínico. Um serv(i)dor pontuou que há um ano estavam em um "clima péssimo", em fase de depoimentos em processo judicial. Todavia, um ano depois, o grupo reconheceu o fortalecimento das relações e do espaço de discussão, propiciando a circulação de afetos e ações colaborativas.

Corrobora-se Safatle (2015) ao afirmar que as sociedades não são simplesmente circuitos de circulação de bens e riquezas. Tais sociedades são circuitos de afetos, e o medo surge como um afeto predominante de circulação na sociabilidade do capital, sobretudo nas organizações que reproduzem o gerencialismo.

Antes de iniciar a última sessão $\left(12^{\mathrm{a}}\right)$, os serv(i)dores estavam colocando os enfeites natalinos na instituição pública federal. $\mathrm{Na}$ ocasião, relataram que, há dois anos, pensaram em doar os enfeites de Natal, ao passo que não havia clima para utilizá-los. Foi importante notar a simbologia dos arranjos que iriam ser jogados fora e que estavam sendo colocados na instituição no final do mês de novembro de 2017 como uma representação de um clima de festa, solidariedade, companheirismo e coletividade. 
Figura 8: Temas centrais identificados na sessão 12

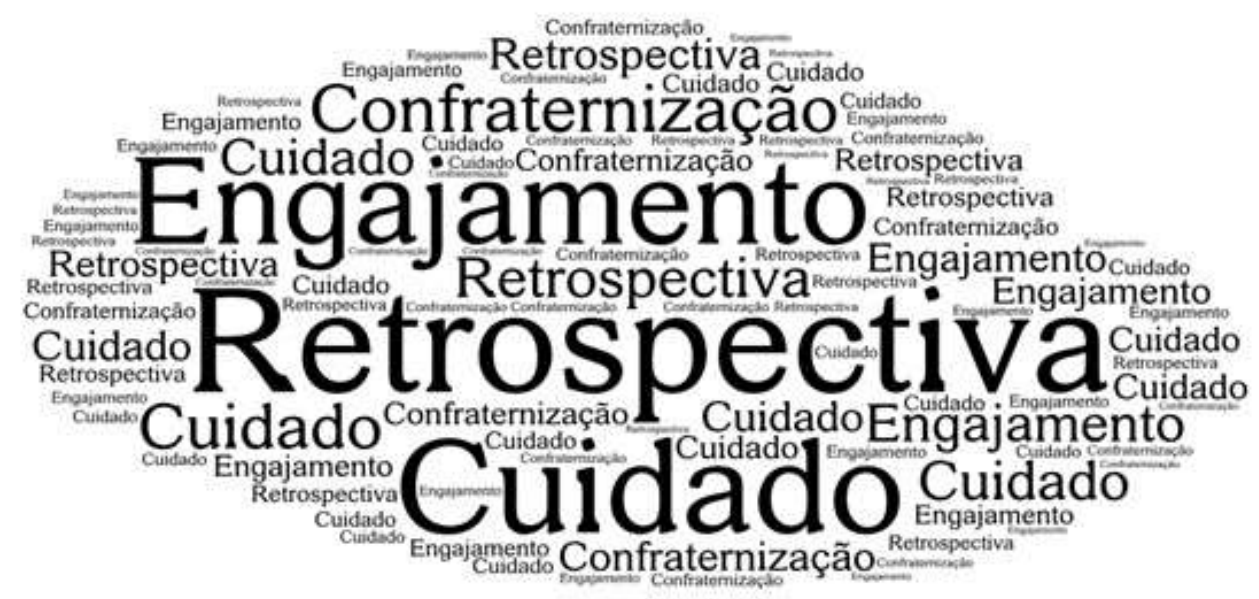

Fonte: Monteiro, 2018.

De modo geral, constatou-se a mudança das narrativas do grupo, pois inicialmente eles visualizavam apenas as situações carregadas de sofrimento, assédio, violência e adoecimento; ou seja, não conseguiam perceber o potencial do coletivo e das possibilidades de criação de contextos de autonomia. Cabe destacar que essa percepção adentra outros âmbitos do trabalho, tornando o serviço penoso e difícil de ser realizado. Porém, ao refletirem sobre o trabalhar, os serv(i)dores reconheceram a força que têm e os projetos começaram a ser colocados em prática, com um desejo de realizar, resolver e caminhar.

\section{Avaliação da escuta clínica do sofrimento no trabalho no grupo de serv(i)dores públicos federais}

A reunião de avaliação aconteceu no dia 26 de junho de 2018. Estiveram presentes 7 serv(i)dores, o gestor atual, a clínica-pesquisadora, a estagiária-pesquisadora e a supervisora do estudo, totalizando assim onze pessoas. O psicólogo do SIASS recebeu o convite, mas não pôde comparecer por não estar em Palmas nessa data.

Inicialmente, a clínica-pesquisadora retomou o que seria a reunião de avaliação proposta por Mendes e Araujo (2012), dando-lhes espaço para falarem sobre como estavam se reinventando no saber-fazer do trabalho. Na sequência, os serv(i)dores começaram a narrar o percurso que estavam trilhando até então:

Fazendo uma retrospectiva assim maior, quando a gente começou no primeiro encontro a gente focou muito na gestão passada, todos os problemas que a gente passou, a transição e aí nas expectativas né dessa nova gestão e tal. Hoje a gente está aqui, acho que tem um ano né que o [gestor atual] tomou posse ... quase um ano. Então, eu percebi que a gente tá voltando ao ritmo normal diante da gestão complicada que a gente teve ... foi uma gestão muito fora da curva e eu estava muito próximo desses problemas, sofri diretamente e tals. Para mim foi um dos piores anos da minha vida. Hoje eu acordo e percebo, assim, nossa, parece que tá normal né?

Foi possível perceber, de forma explícita, que os trabalhadores reconhecem que a gestão atual tem apresentado muitos avanços.

Não é mais ruim acordar e vir trabalhar, porque antes era ruim. Só de falar já traz alívio e também as aberturas que foi tendo para outros diálogos, como ele falou, as mudanças de setores. O ambiente de trabalho ... voltou ao status de normalidade, como se espera que seja. A pessoa levantando cedo, com aquele ânimo de vir trabalhar, fazer do [nome da instituição pública] sua extensão de casa mesmo, por aqui mesmo os servidores almoçam, por aqui mesmo os servidores 
se divertem. Então tem sido um ambiente que não é de exclusividade apenas de trabalho. Tá sendo uma segunda casa e por levar essa denominação de casa, tá sendo até bem agradável.

Essa analogia, "segunda casa", ilustra como o clima organizacional e as relações de trabalho melhoraram. Há também uma valorização do espaço de discussão por parte dos trabalhadores, e o momento foi oportuno para dirigirem o reconhecimento dessa ação ao gestor.

Uma coisa que é importante, é que a gente tá participando da gestão, a gente tá sendo ouvida, nossas opiniões, as decisões, no geral, não estão sendo decididas só por uma única pessoa. $\mathrm{O}$ [gestor atual], ele procura sempre a nossa opinião. . . . Mudou bastante, pois antes a gente não tinha essa abertura para a gente expor as nossas ideias, nossas opiniões, enfim.

O gestor verbalizou que não é uma tarefa fácil criar esses contextos, mas acredita nessa gestão "mais coletivista", justificando já ter tido outras experiências nessa área (gestão).

Ademais, o gestor sinalizou que existe a proposta de viabilizar a criação de um grupo para continuar essas discussões, mas, nos últimos meses, tem sido difícil implementar essa proposta, pois foram atropelados por diversos problemas relacionados ao trabalho (acúmulo de atividades, sobrecarga de trabalho, entre outros).

. . . uma série de contratempos, que as coisas que estavam sendo pensadas para serem implementadas foram deixadas meio que paradas, né. Espero que agora . . . talvez a gente tenha um tempo para pensar e articular melhor, mas agora a gente vem com outro problema, que não tem dinheiro para nada, absolutamente nada.

Assim, percebeu-se que a falta de recursos tem sido um desafio para as instituições públicas em geral, assim como para essa.

Com o intuito de sistematizar os avanços do grupo e desafios do grupo, apresenta-se o seguinte quadro.

Quadro 1: Avanços e desafios do grupo Fala-Escuta

\begin{tabular}{|l|l|}
\hline \multicolumn{1}{|c|}{ Avanços } & \multicolumn{1}{c|}{ Desafios } \\
\hline Comunicação na sede & Liderar uma equipe grande \\
\hline Criação de um site (intranet) & $\begin{array}{l}\text { Melhorar o relacionamento com os serv(i)dores } \\
\text { que trabalham no interior }\end{array}$ \\
\hline Constituição de espaços de discussões & Melhorar o ambiente de trabalho \\
\hline
\end{tabular}

Fonte: Elaborado pelas autoras

Esse espaço de discussão propiciou momentos oportunos para os serv(i)dores nomearem, socializarem e (re)significarem o sofrimento. À vista do exposto, foi possível identificar o potencial político da escuta clínica neste grupo. ". . . A cada mês a gente está melhorando, de pouquinho em pouquinho, se continuar assim, vamos chegar em um nível de excelência”.

Quanto aos desafios com os trabalhadores do interior, o gestor se posicionou de forma empática, concordando com as queixas trazidas por eles, haja vista que as estruturas do interior se encontram bastantes fragilizadas. Chegou a verbalizar que tem lugar que possui apenas um serv(i)dor, desconhecendo como a pessoa mantém a sanidade mental.

A situação é muito precária, isso incomoda eles e a gente também. Toda vez que fazemos uma reunião aqui, a gente está começando a trazer eles uma vez por mês, a gente acaba perdendo algum tempo com eles desabafando, às vezes, não tem nada a ver o assunto. Mas daí, já cai em cima. As reuniões, muitas vezes, acabam se tornando improdutivas.

O termo "improdutivo", adotado pelo gestor, refere-se ao desenrolar dos processos organizacionais, focalizando na tarefa. Todavia, o coletivo de trabalhadores começa a pensar que 
precisam reservar um espaço e determinado tempo para ouvir estes serv(i)dores "desabafarem", ao passo que não foram privilegiados com a escuta clínica do sofrimento no trabalho e, talvez por isso, estejam demandando tanto um espaço de discussão. Acrescentou-se, ainda, que abrir espaços para ouvir os desabafos é também muito produtivo do ponto de vista do afeto, da cooperação, do estreitamento dos laços de solidariedade, pois todos são colegas da mesma instituição, só atuam em cidades com contextos socioeconômicos muito díspares.

Um serv(i)dor acrescenta que ". . . a questão não é desabafar, a gente precisa pensar como vamos proporcionar contextos de mudanças e melhorias para eles também. Só desabafar e ver que não tem retorno, previsão de mudanças e melhorias, não vai melhorar". Com isso, o coletivo de clínicas-pesquisadoras pontuou que essa situação vivenciada pelos trabalhadores do interior foi um movimento muito semelhante ao que o grupo, constituído pelos trabalhadores da sede, passou. Pois, agora, o grupo está à frente de quem não participou do espaço de discussão, porque quem veio pôde falar sobre o que incomodava, tema bastante trabalhado nas três primeiras sessões (narrativa da dor). A partir dessa repetição, começaram a perceber que precisavam fazer alguma coisa, levando um tempo para poderem se mobilizar.

Quando questionados sobre os sentimentos que têm, se fossem nomeá-los, após quase um ano do início da clínica, as palavras valorização e motivação se sobressaíram; em termos psicodinâmicos, eles se sentem reconhecidos. Eles sugeriram fazer um levantamento quantitativo de como está a saúde dos serv(i)dores, via SIASS. Um serv(i)dor afirmou, com propriedade, que o desenho gráfico vai se referir a um pico e, na sequência, uma queda significativa. $O$ gráfico poderá evidenciar como algumas medidas reverteram na qualidade da saúde dos serv(i)dores, mesmo com o fator da sobrecarga de trabalho. Um serv(i)dor brincou: "Era tanto trabalho, que não dava para adoecer não".

Fazendo uma análise dos serv(i)dores que participaram do grupo, percebeu-se que foram criando estratégias de defesas coletivas, foram se blindando para não adoecer. É bem importante reforçar o trabalho do SIASS no Tocantins, que apesar de ser uma equipe muito pequena, se preocupou com a instituição participante deste estudo. Cabe descrever que, no início desta escuta clínica do sofrimento no trabalho, o coletivo de clínicas-pesquisadoras foi convidado para uma reunião com o psicólogo e uma médica do SIASS, os quais queriam saber como o grupo estava e se a instituição tinha condições para receber o ex-gestor, agora, com a função que passou no concurso público. Essa discussão de caso demonstrou o quanto nosso trabalho foi valorizado pelo SIASS, fortalecendo a parceria com o grupo de pesquisa.

Foi perguntado, ao grupo, se eles conseguiram levar as questões trabalhadas no coletivo para os demais serv(i)dores que não participaram; eles responderam que, na sede, a repercussão foi bastante contagiante. Inclusive, como encaminhamento da reunião de apresentação do relatório final para o gestor, realizada no dia 2 de março, o grupo destacou: "Solicitar para a [clínica-pesquisadora] uma nova apresentação com a participação de todos os servidores de Palmas para dar um feedback dos trabalhos desenvolvidos nas reuniões com o Grupo dos 11 servidores voluntários" (Ata de Reunião do processo de fala-escuta ${ }^{7}, 2$ de mar. 2018).

Essa deliberação foi analisada pelo coletivo de clínicas-pesquisadoras como um desejo do grupo de transmitir os avanços aos demais, mas foi trabalhado em supervisão que esse não era o nosso papel, vislumbrando, assim, uma outra demanda, uma vez que na reunião-convite esses não tiveram interesse em participar. Então, de forma cuidadosa, a clínica-pesquisadora acolheu a demanda, reforçando que o próprio grupo teria potencial para fazer isso, visto que já haviam apresentado ao gestor.

O Grupo Fala-Escuta foi mencionado na reunião de avaliação como sendo uma válvula de escape.

Nós tivemos o fala-escuta como uma válvula de escape, o pessoal das agências eles tiveram, talvez não na mesma proporcionalidade, o envolvimento direto com o [ex-gestor], mas eles também foram assolados em algumas situações com bastante desrespeito também. Então, era um público

7 Esta ata foi encaminhada por uma servidora do grupo para o e-mail da clínica-pesquisadora. Consistiu no registro das pautas que foram elencadas na reunião com o gestor para discussão do relatório final. 
que caberia muito bem naquelas reuniões. Mas devido a nossa estrutura . .., impedimento do próprio trabalho, ... f foi um grupo que não teve a oportunidade de ter esse escape. Eles ainda carregam, de certa forma, marcas desse passado.

Outros serv(i)dores acrescentaram que ". . . aqui dentro da sede, eu acredito que houve sim uma melhora do clima organizacional. Isso sem dúvidas". "Nós já estamos colhendo os frutos desse processo". Um trabalhador pede para dar a palavra final, trazendo uma narrativa voltada para a formação da consciência coletiva.

... me recordo quando tivemos a primeira reunião com o pessoal da auditoria, eles vieram aqui, começamos a fazer alguns relatos ... uma coisa é consciência individual, estou apanhando, mas sei que não posso apanhar assim. Agora a formação da consciência coletiva é muito difícil, mas quando a consciência coletiva é formada na dor, na prática, não é questão que você se debruçou sobre livros e livros, para ler teoria e formar uma consciência coletiva, aprendeu fazendo, aprendeu sofrendo, passou pelo processo e, nesse sentido, eu acho que a equipe cresceu muito. A dor anterior, a experiência que está vivenciando agora, eu costumo dizer que você cria uma casca, o pessoal daqui está com uma casca grossa . . . quer queira, quer não, você tem uma equipe que hoje está com um consciente coletivo que, a princípio vai ser sempre defesa para se resguardar, para não permitir que isso jamais aconteça novamente.

Esse trecho nos remete ao saber-fazer, sendo perceptível a mudança das narrativas do grupo, que (re)significou os sofrimentos vivenciados no contexto de trabalho, reestruturando as estratégias defensivas para agirem sobre o real do trabalho.

A reunião de avaliação foi encerrada com clima de gratidão, tanto por parte do coletivo de clínicas-pesquisadoras quanto do grupo de serv(i)dores.

...Eu gostaria de parabenizar vocês pela iniciativa, é muito difícil você identificar programas, projetos, ações, iniciativas como essa que completa ciclos, a maioria vem, até parece uma coisa nita, interessante, mas é difícil de você completar o ciclo... O comprometimento de vocês com o projeto é de se exaltar.

\section{Discussão}

Neste estudo, a análise da demanda foi permeada por um triplo desejo, quais sejam: o programa de pós-graduação representado pela clínica-pesquisadora e supervisora que procuraram o SIASS em busca de um órgão que tivesse demanda por uma escuta clínica. Este, por sua vez, acatou a solicitação, realizando assim uma parceria informal com o grupo de pesquisa Trabalho e Emancipação: Coletivo de Pesquisa e Extensão. O desejo do SIASS partiu de atender uma instituição que estava demandando muito deles e, por terem uma equipe reduzida, acharam que o apoio institucional da universidade federal seria uma boa alternativa para eles, mas, sobretudo, para a instituição pública federal à qual os participantes estavam vinculados. $O$ terceiro desejo foi o da própria organização, que prontamente aceitou a proposta de parceria demandada pelas clínicas-pesquisadoras e pelo SIASS.

Destaca-se que a mobilização subjetiva não é exclusiva para aqueles que participam das sessões, pertencendo, inclusive, ao coletivo de clínicas-pesquisadoras. Na condução clínica deste estudo, o engajamento e o envolvimento das clínicas-pesquisadoras foram requisitos fundamentais. Abster-se da posição de expert da vida do outro e, juntos, construírem caminhos possíveis para que a mobilização subjetiva acontecesse fez com que as clínicas-pesquisadoras também se movimentassem para experienciar o novo e o mar de possibilidades.

Vivenciar os dispositivos clínicos constituiu um ganho tanto para os serv(i)dores quanto para o coletivo de clínicas-pesquisadoras, ao passo que possibilitou o encontro de diversas vozes que buscavam (re)significar o passado e o agora por meio da escuta clínica propriamente dita. 
Decidiu-se ampliar o foco, os discursos isolados saíram de cena e as narrativas ditavam um modo coletivo de ser/estar no mundo.

De acordo com Périlleux (2013) e Mendes (2014), o material produzido no/pelo grupo pertence ao coletivo, não podendo ser endereçado a nenhum trabalhador de forma individual. Do mesmo modo, ressaltaram que os trabalhadores pertencentes ao coletivo são as pessoas mais indicadas para sugerir mudanças na organização do trabalho. Merlo et al. (2013, p. 149), alertaram que ". . . muitas vezes é somente quando se fala e se é escutado - por si mesmo e pelos outros - que o trabalhador se dá conta do 'milagre da palavra"”.

Nas sessões, os serv(i)dores relataram detalhes sobre a relação com os pares e as chefias, assim como distinguiram a gestão em três momentos: a gestão anterior, a gestão-tampão e a gestão atual. Pontuaram que a gestão anterior adotou um padrão de comportamento burocrático (obsessivo). Foi possível visualizar que, nesse período, em termos de infraestrutura, a organização obteve grandes avanços, sendo o maior deles a mudança para um prédio com excelente localização. Contudo, nas relações interpessoais, deixou muito a desejar, sendo caracterizada pelos participantes como a "pior época em relações humanas". Esse padrão de comportamento corrobora o estilo de gestão que tem sido adotado pelo serviço público, o gerencialista, aquele voltado para a centralização do poder de forma autoritária, não garantindo a participação da sociedade civil nas tomadas de decisões.

Gaulejac (2005) afirma que a gestão é apresentada como uma tecnologia de poder, embora ele ressalte a importância de fazermos uma gestão humana de recursos (em contraposição à gestão de recursos humanos). Para esse autor, a guerra econômica que se vive com o capitalismo acaba por justificar o empoderamento empresarial frente a outras instituições, como também para os sacrifícios exigidos dos trabalhadores cotidianamente. Fato que se intensificou com a ditadura em tempo real das novas tecnologias de comunicação, ou seja, o ritmo da vida dos sujeitos, tanto social como organizacional, passa a ser determinado pelo ritmo das corporações, eis a potência impregnada do gerencialismo.

De acordo com Paes de Paula (2005), a administração pública gerencial está focada no controle dos resultados e na eficiência dos serviços ofertados (aumento do desempenho). O protagonismo da reforma gerencial tem desconsiderado de forma expressiva os contextos culturais, bem como as especificidades da área pública. Traesel e Merlo (2014) estudaram as vivências dos trabalhadores públicos que foram bastante impactados pela reforma gerencial. Nesse estudo, identificaram que os resultados econômicos sobressaíam aos resultados sociais.

Para Antunes (2013, 2018), a precarização do trabalho, a flexibilidade, as desregulamentações dos contratos de trabalho atuam de maneira central na nova reestruturação produtiva. Essa dinâmica se alastra também para o setor público, que tem sofrido no trabalho por questões éticas, de sobrecarga, resultando assim em um desgaste mental (Seligmann-Silva, 2011).

Na gestão-tampão não houve muitos avanços; nas falas de alguns, "ele apenas guiou o barco". Os serv(i)dores relataram que o gestor possuía um vasto conhecimento dos processos de trabalho da instituição pública federal, mas que não tomou decisões potenciais na época em que assumiu a chefia. Segundo os participantes, essas decisões que não foram tomadas respingam na gestão atual.

Em contrapartida, verificou-se que o sofrimento do trabalho advinha não só da gestão anterior, mas era potencializado pelos processos de trabalho da gestão atual, com sobrecargas. Entretanto, foi possível observar que a gestão atual se encontra preocupada com a saúde mental de seus serv(i)dores.

No que se refere à organização do trabalho, a sobrecarga foi um tema amplamente discutido e catalisador de sofrimento e adoecimento no contexto de trabalho dos serv(i)dores. Menezes de Carvalho e Moraes (2011) estudaram o processo de adoecimento no trabalho no Polo Industrial de Manaus, sendo que a organização do trabalho foi também marcada pela sobrecarga, assim como outros elementos patogênicos relacionados às formas de gestão.

Ademais, dentre as queixas relacionadas à divisão do trabalho, os personagens narraram a urgente necessidade de o organograma prescrito ser (re)pensado, por estar distante do organograma real. Para a psicodinâmica do trabalho, inegavelmente, há uma lacuna entre o 
trabalho prescrito e o trabalho real, pois não há como deduzir com precisão a realidade de um trabalho (Facas, 2013). Quando se quer que os trabalhadores respeitem de forma efetiva o prescrito, Dejours (1986) distinguiu que a hierarquia e o controle se tornam imperativos para que isso aconteça.

Outrossim, as condições de trabalho dos serv(i)dores alocados no interior também estiveram presentes nas narrativas. Segundo os trabalhadores da sede (Palmas-TO), eles possuem condições precárias de trabalho, infraestrutura decadente e falta de recursos materiais e humanos. Por vezes, não conseguem compreender os ritmos e os prazos dos processos de trabalho da sede, causando um desgaste na relação entre os trabalhadores da sede e os trabalhadores do interior.

Para aquisição dos recursos tanto materiais quanto humanos, precisam recorrer à organização do trabalho da sede; para a maioria deles (trabalhadores do interior), há uma morosidade das tarefas desempenhadas pela equipe da sede. Com o espaço de discussão, os sujeitos relataram ter sido uma pena os serv(i)dores do interior não terem participado, assim como compreendem que a comunicação com eles precisa ser melhorada. Cabe destacar que, na reunião convite, já sinalizaram a importância de o pessoal do interior participar do Grupo FalaEscuta, uma forma de dizer que esses trabalhadores também tinham problemas, apesar de não terem sofrido o "assédio moral" de forma direta. A necessidade de participação dos serv(i)dores alocados no interior ressurgiu nas sessões com o coletivo e na reunião de avaliação.

Segundo Rebechi e Figaro (2013), a comunicação deve ultrapassar o viés funcionalista, delimitado como aquele que se centra somente nas estruturas de eficácia e eficiência em prol da "boa comunicação". Quando os serv(i)dores se referem à melhoria da comunicação, não estão se restringindo à transmissão de informação (emissor-receptor), ao passo que foi possível observar nas narrativas que estão considerando os aspectos relacionais e interacionistas, posto que consideram lamentável não ter ampliado o espaço de discussão com os trabalhadores do interior. Como encaminhamento do Grupo Fala-Escuta, os serv(i)dores estão se organizando para fazer reuniões mensais, na intenção de que eles possam se relacionar melhor, estreitar os laços e promover a cooperação e solidariedade.

Figaro (2008) destacou que o trabalhar sedia as relações comunicacionais, construindo, assim, a realidade social dos sujeitos. Nesta prática clínica, foi possível visualizar o avanço do grupo com relação à comunicação entre os pares, mas, sobretudo, com a chefia, visto que o coletivo de serv(i)dores se aproximou da gestão para narrar sobre os percalços da organização do trabalho. Cabe refletir, então, que o espaço de discussão é um contexto propício para que essas relações comunicacionais se movimentem. Esse cenário pode ser pensado como sendo um lugar fértil para implementar políticas que vislumbrem a saúde mental do serv(i)dor. Como foi visto, a sobrecarga e as condições de trabalho são aspectos da organização que precisam ser mais assistidos, sendo que, para além dos recursos físicos, os sujeitos buscam o reconhecimento no trabalho.

O reconhecimento consiste no processo de valorizar o esforço e as energias investidas pelo trabalhador para a realização das atividades laborais, muitas vezes repletas de cargas de sofrimento (Cruz Lima, 2013; Dejours, 2011). Esse percurso permite que o sujeito construa sua identidade, traduzida pelas vivências de prazer e de autorrealização. Logo, o sentido atribuído ao sofrimento no trabalho depende do fator reconhecimento. Isto é, conforme o trabalhador é reconhecido no/pelo trabalho, abre espaço para que este reflita e atribua sentido às suas frustrações e dúvidas, passando a olhar, dessa forma, de um jeito novo, diferente. Nesse processo clínico, o fato de o gestor atual ter aceitado a realização desta pesquisa de escuta clínica do sofrimento no trabalho foi uma atitude interpretada pelo coletivo como uma forma de reconhecimento.

Vale ressaltar que várias faces da violência foram retratadas, dentre elas: pressão para atingir metas inatingíveis, excesso de trabalho, gestão autoritária (gestão anterior), ameaças e assédio moral. Nesse contexto, houve violência explícita, que foi alcançando os serv(i)dores de forma isolada. Eles nomearam que o ex-gestor escolhia a "bola da vez"; passados mais de dois anos, perceberam que aquela situação não podia ser naturalizada, pois várias pessoas já tinham sido o alvo. Farias (2013) destacou que nem sempre a violência é nítida, ao passo que pode ser 
dissimulada pelas práticas organizacionais, que utilizam recursos de sedução. Nesse caso, alguns serv(i)dores relataram que sofreram indiretamente.

A violência passou a ser concebida e nomeada por eles de assédio moral. De acordo com Heloani e Barreto (2013, p. 56), "o assédio moral constitui uma violação dos direitos fundamentais e uma mácula à dignidade humana". Por sua vez, Heloani e Barreto (2018) relataram também que, no Brasil, as pesquisas têm demonstrado que a duração do assédio moral compreende o período entre seis e doze meses. Contudo, Barreto (2005) destacou que a duração pode sofrer uma variação de três meses a mais de três anos. Nas organizações públicas, essa violência tende a se estender, jogando o servidor de um lado para o outro. No Grupo Fala-Escuta, esse fenômeno foi possível de ser visualizado quando os participantes narravam que o antigo chefe "escolhia" o serv(i)dor que seria "a bola da vez", sendo que a duração da violência ultrapassou os três anos.

Nesta pesquisa, optou-se por analisar a violência no trabalho a partir da abordagem psicossocial, entendendo que não se configura como um problema individual, mas por uma situação conjunta orquestrada pelas interações existentes na organização do trabalho. A forma como o trabalho é solicitado e organizado (sobretudo pelo gerencialismo) também pode suscitar o surgimento do assédio moral. Na instituição pesquisada, foi possível visualizar o assédio moral interpessoal, assim como o assédio moral organizacional, visto que as formas de violência também eram estampadas nas políticas e nas práticas organizacionais, ora sutis, ora explícitas.

Dentre as patologias relatadas pelos trabalhadores, a depressão e a fibromialgia foram as mais mencionadas. Nesse ponto, essa pesquisa converge com os achados de Amaral (2018), que realizou uma escuta clínica do trabalho com professoras readaptadas e, em se tratando de patologias, a depressão e a fibromialgia também foram as mais citadas.

Nesta escuta clínica com os serv(i)dores, as narrativas traziam sintomas de um grupo que (sobre)viveu em meio ao caos organizacional. Para lidar com esses sofrimentos, constituíram sistemas defensivos individuais e coletivos, sendo que a negação e a autoaceleração emergiram como principais estratégias defensivas utilizadas pelo coletivo. Moraes (2013a) apontou que a negação constitui um dos mecanismos psicológicos mais utilizados como estratégia de defesa, ao passo que "nega-se o fato de que a organização do trabalho é a causa do sofrimento, responsabilizando-se o indivíduo pelo problema" (Moraes, 2013a, p. 154).

Foi possível identificar, no grupo, estratégias defensivas individuais e coletivas de negação, muitas vezes caracterizadas pela desconfiança, pelo individualismo e pelo isolamento, atribuindo as falhas como consequência do despreparo e da incompetência de alguns. Este sistema defensivo é caracterizado por Dejours (2011) como sendo defesas de adaptação e exploração, pois o trabalhador nega o sofrimento e submete seus desejos aos objetivos organizacionais, assumindo as metas da produção como suas. Esse modo de pensar e agir pode conduzir a um contexto de alienação.

A defesa exploradora da autoaceleração foi visualizada no grupo como um sintoma que funcionava em favor do aumento da produção. Segundo Mendes (2007), as estratégias defensivas minimizam os efeitos nocivos produzidos pela organização do trabalho, atuando de maneira protetora, adaptativa ou exploradora, com vistas a manter, ainda que de maneira inconsistente, a saúde mental. Todavia, essas estratégias não suscitam as vivências de prazer no trabalho.

Foi possível constatar também o sofrimento criativo, que se destina à engenhosidade e à criação de soluções para os empecilhos decorrentes do trabalho. Nesse caso, tal sofrimento atuou como um mobilizador para mudar o real do trabalho, trazendo benefícios para a organização do trabalho assim como colaborou para a realização pessoal. Moraes (2013b) delineou que, para que o sofrimento se torne criativo, é necessário que seja subvertido em prazer por meio da inteligência prática.

Observou-se que o sofrimento criativo emergia nas sessões a partir do uso de metáforas, momento em que os trabalhadores despertavam para pensar a organização do trabalho a partir de uma forma engenhosa, fomentando ações para mudar o trabalho por meio da inteligência prática. A título de exemplo, reuniram-se para apresentar as demandas do grupo ao gestor atual. De início enviaram um e-mail com as pautas predefinidas solicitando uma reunião. A metáfora 
que potencializou essa mobilização foi "Não basta ter a faca e o queijo na mão, é preciso ter fome!". Esse recurso foi apresentado ao coletivo via memorial. Essa inteligência envolve a cognição e a afetividade, e não se restringe, portanto, ao processo mental cognitivo.

De acordo com Dejours (2011), a inteligência prática é astuciosa e pulsional, pois precisa dar conta dos imprevistos inerentes ao trabalho. Ela é espontânea e se manifesta em busca do sentido no trabalho. Vasconcelos (2013, p. 238) acrescentou que essa inteligência está "enraizada no corpo" e compreende "um conhecimento corporificado, histórico e cultural". Os resultados da ação, obtidos por meio da inteligência prática, conferem maior relevância ao trajeto percorrido para alcançá-los.

De outro lado, o sofrimento pode tomar um caminho diferente, o patogênico. Isso acontece quando o trabalhador não consegue meios de negociação com a organização do trabalho e, desse modo, sua capacidade inventiva fica castrada (Moraes, 2013b). O sofrimento patogênico emergiu ao longo das sessões, deixando claro que foi um grupo que passou por situações constrangedoras e opressoras. Além de ter as relações interpessoais minadas, a falta de reconhecimento no trabalho foi um fator desencadeador para potencializar o contexto de sofrimento.

Nesta clínica com os serv(i)dores, foi possível perceber a potência do espaço de discussão, que favoreceu a elaboração e a perlaboração dos conteúdos recalcados vigentes no grupo de trabalhadores. Segundo Laplanche e Pontalis (1992, p. 339), a perlaboração constitui o "processo pelo qual a análise integra uma interpretação e supera as resistências que ela suscita", possibilitando, dessa forma, a aceitação dos elementos recalcados pelo sujeito, que se liberta da influência dos mecanismos repetitivos (elaboração interpretativa).

A construção deste espaço possibilitou que os sujeitos se (re)construíssem por meio da cooperação e dos vínculos de confiança e afeto. Para Merlo et al. (2013), esse espaço genuíno é o lugar para os trabalhadores problematizarem suas questões de forma livre, sem que haja julgamentos. Por meio do uso da palavra e da escuta, emergem as elaborações dos conteúdos que foram problematizados, com vistas a resgatar os vínculos de cooperação e solidariedade entre os sujeitos.

A mobilização dos serv(i)dores públicos federais traduziu um avanço para o coletivo como um todo que, por meio do sofrimento criativo, da inteligência prática, do espaço de discussão, da cooperação e do reconhecimento, conseguiu construir contextos de autonomia para mudar o trabalho. Esta emancipação do coletivo foi essencial para que a mobilização subjetiva entrasse em cena.

Mendes e Duarte (2013) descreveram que a mobilização subjetiva é caracterizada como sendo um processo intersubjetivo, o que significa dizer que envolve o engajamento do trabalhador no próprio espaço de discussão. Tais autoras ressaltaram a importância da contribuição-retribuição simbólica, que consiste no reconhecimento do trabalhador pelos pares e pela chefia. "Por trás da mobilização subjetiva, há a busca da identidade; o sujeito não quer só executar a tarefa; quer dar vida ao trabalho, deixar sua marca" (Mendes \& Duarte, 2013, p. 261).

Foi possível constatar que o trabalho do grupo de serv(i)dores públicos federais pesquisados em Palmas - TO transitou por contextos de (re)significação. O que antes era um ambiente adoecedor passa a ser olhado como um cenário de possibilidades, denominado por eles de "curva da normalidade". Dejours (1986) propôs a "normalidade" como um objeto de estudo a ser debruçado pela psicodinâmica do trabalho; nesse passo, abriu caminhos para que o prazer no trabalho também fosse abordado, não somente o sofrimento.

Dessa forma, o termo "curva da normalidade", utilizado pelos participantes, refere-se ao novo momento que estão vivenciando, marcado pelo prazer de ir trabalhar, diferentemente do que acontecia na época da gestão passada. A constituição do espaço de discussão propiciou que as narrativas de sofrimento se deslocassem para as deliberações, etapa fundamental para que a mobilização subjetiva acontecesse. 


\section{Considerações finais}

A fala que inicia o título deste artigo é significativa porque surgiu na 1ํ Sessão, uma forma de trazer à tona o sofrimento vivenciado ao longo dos últimos 4 anos, mas carregado de um desejo de mudança para o coletivo de serv(i)dores:

... Nós passamos por uns "maus bocados" na última gestão, situações que ninguém quer vivenciar novamente. E acho que várias das pessoas que aceitaram tá aqui conversando, pra aprender a ser melhor com a gente mesmo, com os nossos pares, nós erramos, ninguém erra sozinho. Sempre concordo que aonde for, qual a parte que me toca naquele processo. E nós queremos construir algo novo aí nesse processo também (Transcrição da 1를 Sessão, 5 set. 2017).

$\mathrm{Na}$ condução dessa escuta clínica, acessaram-se narrativas carregadas de muita dor, sendo o sofrimento no trabalho recorrente. Agressões verbais, violência moral e psicológica eram constantemente (re)vividas. Entender o tempo e o ritmo do outro também foi um exercício diário por parte da clínica-pesquisadora, pois aprender a lidar com o silêncio requereu uma maturidade que o próprio processo clínico foi instigando. As supervisões foram momentos cruciais para que a clínica-pesquisadora e a estagiária-pesquisadora pudessem entender as mudanças de narrativas dos serv(i)dores.

Percebeu-se, por meio das narrativas dos participantes do estudo, um movimento no grupo ao longo da escuta clínica. Em um primeiro momento, permaneceram na queixa e na repetição, mas, ao longo das sessões, puderam acessar a dor por meio da fala, das discussões, elaborando, perlaborando. Observou-se que a repetição foi necessária para que pudessem (re)significar o sofrimento e assim vivenciar o prazer em serem trabalhadores da instituição pública federal.

O nível de escolaridade que prevaleceu entre os participantes foi a pós-graduação. Esse perfil, aliado ao envolvimento da gestão da instituição pública federal, assim como dos próprios serv(i)dores em buscar o sentido no trabalho, pode ter favorecido a mudança de narrativa do grupo, tendo em vista a facilidade de elaboração dos conteúdos discutidos nas sessões. Trata-se ainda de uma lacuna a ser aprofundada em estudos futuros, sobretudo se há prevalência de nível de escolaridade com mudança de narrativa em grupos de escutas clínicas do trabalho. Um outro aspecto importante é o fato de já terem passado por outros espaços para falar da dor sofrida na gestão anterior (via SIASS, Ministério Público e Sindicato).

No que concerne ao uso dos dispositivos clínicos de escuta do sofrimento, ressalta-se que a análise da demanda, a transferência e a interpretação foram vivenciadas durante todo o processo clínico. A partir da escuta clínica do trabalho realizada, observou-se que os serv(i)dores se fortaleceram diante dos efeitos promovidos pelo assédio moral. $O$ espaço de discussão possibilitou que os trabalhadores compartilhassem suas dores em relação à violência sofrida no trabalho, assim como avaliassem o impacto da sobrecarga de trabalho presente no momento atual.

Foi possível visualizar, ainda, o resgaste de sentido nesta clínica, uma vez que os serv(i)dores reconheceram as mudanças que tiveram na comunicação entre os pares da sede, legitimando a importância de constituir outro espaço público de discussão assim que este processo clínico findasse. Sobre os desafios, pontuaram que ainda precisam melhorar o ambiente de trabalho e o relacionamento interpessoal e profissional com os serv(i)dores que trabalham no interior, declarando ter sido uma pena eles não poderem participar desta escuta clínica, por questões de logística e escassez de recursos financeiros.

Com o fim desta escuta clínica do sofrimento no trabalho, conclui-se que o uso dos dispositivos clínicos permitiu que os serv(i)dores mudassem suas narrativas (e atitudes frente ao trabalho), visto que atribuíram novos sentidos ao trabalho, (re)significando, assim, os conteúdos que desencadearam sofrimento intenso. Desse modo, percebeu-se que houve uma reorganização do sistema defensivo. Confirma-se, dessa forma, a importância da clínica como potencial político de organização coletiva. 


\section{Referências}

Alves, J. J. (2014). Mobilização subjetiva para o prazer-sofrimento no trabalho dos taquígrafos parlamentares: uma prática em clínica psicodinâmica da cooperação [Dissertação de Mestrado em Psicologia Social do Trabalho e das Organizações, Universidade de Brasília].

Amaral, G. A. (2018). Escuta clínica do trabalho e (re)significação do sofrimento de professoras readaptadas. [Tese de Doutorado em Psicologia Social, do Trabalho e Organizações, Universidade de Brasília].

Antunes, R. (2013). Desenhando a nova morfologia do trabalho e suas principais manifestações. In A. M. Mendes, R. D. Moraes, \& A. R. C. Merlo (Orgs.), Trabalho e sofrimento: práticas clínicas e políticas (pp. 25-45). Juruá.

Antunes, R. (2018). O privilégio da servidão: o novo proletariado de serviços na era digital (1ª ed.). Boitempo.

Barreto, M. M. S. (2005). Assédio moral: a violência sutil - análise epidemiológica e psicossocial no trabalho no Brasil. [Tese de Doutorado em Psicologia, Pontifícia Universidade Católica de São Paulo].

Cruz Lima, S. C. (2013). Reconhecimento no trabalho. In F. O. Vieira, A. M. Mendes, \& A. R. C. Merlo (Orgs.), Dicionário crítico de gestão e psicodinâmica do trabalho (pp. 351-355). Juruá.

Dejours, C. (1986). Por um novo conceito de saúde. Revista Brasileira de Saúde Ocupacional, 14(54), 7-11

Dejours, C. (2004). Subjetividade, trabalho e ação. Revista Produção, 14(3), 27-34. https://doi.org/10.1590/S010365132004000300004

Dejours. C. (2011). A Metodologia em psicodinâmica do trabalho. In S. Lancman \& L. I. Sznelwar (Orgs.), Christophe Dejours: da psicopatologia à psicodinâmica do trabalho (pp. 125-150). Paralelo 1.

Duarte, F. C. (2014). Dispositivos para a escuta clínica do sofrimento no trabalho: entre a clínica da cooperação e das patologias. [Dissertação de Mestrado em Psicologia Social do Trabalho e das Organizações, Universidade de Brasília].

Facas, E. P. (2013). Protocolo de avaliação dos riscos psicossociais no trabalho: contribuições da psicodinâmica do trabalho. [Tese de Doutorado em Psicologia Social, do Trabalho e das Organizações, Universidade de Brasília].

Facas, E. P., Fischer, H. C. R., \& Ghizoni, L. D. (2017). Clínica psicodinâmica do trabalho com gestores de uma unidade de taquigrafia parlamentar. Trabalho (En)Cena, 2(1), 117-131. https://sistemas.uft.edu.br/periodicos/index.php/encena/article/view/3993

Farias, J. H. (2013). Violência no trabalho. In F. O. Vieira, A. M. Mendes, \& A. R. C. Merlo (Orgs.), Dicionário crítico de gestão e psicodinâmica do trabalho (pp. 489-498). Juruá

Ferri, M. R. (2003). Os saberes do funcionário público na administração municipal: um estudo de caso em um município de pequeno porte. [Dissertação de Mestrado em Administração, Universidade Estadual de Maringá].

Figaro, R. (2008). Relações de comunicação no mundo do trabalho. Annablume.

Flick, U. (2009). Introdução à pesquisa qualitativa (3르. ed.). Artmed.

França, B. H. (1993). O Barnabé: consciência política do pequeno funcionário público. Cortez.

Gama, P. L., Mendes, A. M., Araújo, J. P., Galvão, M. G. A., \& Vieira, F. O. (2016). Ressignificação do sofrimento: clínica do trabalho em um hospital escola. Revista Laborativa, 5(1), 38-63. https://ojs.unesp.br/index.php/rlaborativa/article/view/1410

Gaulejac, V. (2005). La société malade de la gestion: idéologie gestionnaire, pouvoir managérial et harcèlement social. Editions du Seuil.

Gerhardt, T. E. \& Silveira, D. T. (2009). Métodos de pesquisa. EdUFRGS.

Ghizoni, L. D. (2013). Clínica Psicodinâmica da Cooperação na Associação de Catadores e Catadoras de Materiais Recicláveis da Região Centro Norte de Palmas - -TO (ASCAMPA). [Tese de Doutorado em Psicologia Social, do Trabalho e Organizações, Universidade de Brasília]. 
"Nós passamos por uns maus bocados": análise das narrativas dos serv(i)dores públicos federais sobre o trabalhar

Ghizoni, L. D. \& Mendes, A. M. (2014). Dispositivos para uma escuta clínica do sofrimento no trabalho dos catadores de materiais recicláveis. Contextos Clínicos, 7(1), 15-26. http://dx.doi.org/10.4013/ctc.2014.71.02

Heloani, R. \& Barreto, M. (2013). Assédio Moral e Sexual. In F. O. Vieira, A. M. Mendes, \& A. R. C. Merlo (Orgs.). Dicionário crítico de gestão e psicodinâmica do trabalho (pp. 55-59). Juruá.

Heloani, R. \& Barreto, M. (2018). Assédio moral: gestão por humilhação. Juruá.

Laplanche, J. \& Pontalis, J. B. (1992). Vocabulário da Psicanálise. Martins Fontes.

Lhuilier, D. (2011). Filiações teóricas das clínicas do trabalho. In P. F. Bendassolli \& L. A. Soboll (Orgs.), Clínicas do Trabalho: novas perspectivas para compreensão do trabalho na atualidade (pp. 22-58). Atlas.

Mendes, A. M. (2007). Da psicodinâmica à psicopatologia do trabalho. In A. M. Mendes (Org.). Psicodinâmica do trabalho: teoria, método e pesquisas (pp. 29-48). Casa do Psicólogo.

Mendes, A. M. (2014). Escuta Analítica do Sofrimento e o saber-fazer do clínico no trabalho. In A. M. Mendes \& R. D. Moraes \& A. R. C. Merlo (Orgs.), Trabalho e sofrimento: práticas clínicas e políticas (pp. 65-80). Juruá.

Mendes, A. M. \& Araujo, K. R. (2012). Clínica da psicodinâmica do trabalho: o sujeito em ação. Juruá.

Mendes, A. M. \& Duarte, F. S. (2013). Mobilização subjetiva. In F. O. Vieira, A. M. Mendes, \& A. R. C. Merlo (Orgs.), Dicionário crítico de gestão e psicodinâmica do trabalho (pp. 259-262). Juruá.

Mendes, A. M. \& Ghizoni, L. D. (2016). Sofrimento como potência política para o trabalho do sujeito vivo. Revista Trabalho (En)Cena, $1(2)$,

$1-3$. https://sistemas.uft.edu.br/periodicos/index.php/encena/article/view/3342/9691

Menezes de Carvalho, G. \& Moraes, R. D. (2011). Sobrecarga de trabalho e adoecimento no Polo Industrial de $\begin{array}{llll}\text { Manaus. } & \text { Psicologia } & \text { 46 } & \text { 46 }\end{array}$ http://pepsic.bvsalud.org/scielo.php?script=sci_arttext\&pid=S1677$11682011000300009 \& \operatorname{lng}=\mathrm{pt} \& \mathrm{nrm}=\mathrm{iso}$

Merlo, A. R. C., Bottega, C. G., \& Magnus, C. N. (2013). Espaço público de discussão. In F. O. Vieira, A. M. Mendes, \& A. R. C. Merlo (Orgs.), Dicionário crítico de gestão e psicodinâmica do trabalho (pp. 147-151). Juruá.

Monteiro, T. M. (2018). "Nós passamos por uns maus bocados": análise das narrativas do trabalho dos serv (i)dores públicos federais. [Dissertação de Mestrado em Comunicação e Sociedade, Universidade Federal do Tocantins].

Moraes, R. D. (2013a). Estratégias defensivas. In F. O. Vieira, A. M. Mendes, \& A. R. C. Merlo (Orgs.), Dicionário crítico de gestão e psicodinâmica do trabalho (pp. 153-158). Juruá.

Moraes, R. D. (2013b). Sofrimento criativo e patogênico. In F. O. Vieira, A. M. Mendes \& A. R. C. Merlo (Eds.), Dicionário crítico de gestão e psicodinâmica do trabalho (pp. 415-419). Juruá.

Paes De Paula, A. P. (2005). Administração pública brasileira entre o gerencialismo e a gestão social. Revista de Administração de Empresas, 45(1), 36-49. http://www.scielo.br/scielo.php?script=sci_arttext\&pid=S0034$75902005000100005 \& \operatorname{lng}=\mathrm{pt} \& \mathrm{nrm}=\mathrm{iso}$

Périlleux, T. (2013). O Trabalho e os destinos políticos do sofrimento. In A. R. C. Merlo, A. M. Mendes, \& R. D. Moraes (Orgs.), O sujeito no trabalho: entre a saúde e a patologia (pp. 73-92). Juruá.

Périlleux, T. \& Mendes, A. M. (2015). O enigma dos sintomas: proposição para uma escuta psicanalítica e política do sofrimento no trabalho. Trivium, 7(1), 61-73. http://pepsic.bvsalud.org/pdf/trivium/v7n1/v7n1a07.pdf

Rebechi, C. N. \& Figaro, R. (2013). A comunicação no mundo do trabalho e a comunicação da organização: duas dimensões distintas. Animus. Revista Interamericana de Comunicação Midiática, 12 (23), 1-21. https://periodicos.ufsm.br/animus/article/view/10811/pdf_1

Safatle, V. (2015). Circuito dos afetos: corpos políticos, desamparo, fim do indivíduo. Cosac Naify.

Seligmann-Silva, E. (2011). Trabalho e desgaste mental: o direito de ser dono de si mesmo. Cortez.

Silva, E. L. \& Menezes, E. M. (2001). Metodologia da pesquisa e elaboração de dissertação (3ํa ed.). Laboratório de Ensino a Distância da UFSC. 
Siqueira, M. V. S. \& Mendes, A. M. (2009). A gestão de pessoas no setor público e a reprodução do discurso do setor privado. Revista do Serviço Público, 60(3), 241-250. https://revista.enap.gov.br/index.php/RSP/article/view/25

Traesel, E. S. \& Merlo, A. R. C. (2014). "Somos sobreviventes": vivências de servidores públicos de uma instituição de seguridade social diante dos novos modos de gestão e a precarização do trabalho na reforma gerencial do serviço público. Cadernos de Psicologia Social do Trabalho, 17(2), 224-238. https://doi.org/10.11606/issn.1981-0490.v17i2p224-238

Triviños, A. (1987). Introdução à pesquisa em ciências sociais: a pesquisa qualitativa em educação. Atlas.

Vasconcelos, A. C. L. (2013). Inteligência Prática. In F. O. Vieira, A. M. Mendes, \& A. R. C. Merlo (Orgs.), Dicionário crítico de gestão e psicodinâmica do trabalho (pp. 237-242). Juruá.

Endereço para correspondência thais.monteiropsi@gmail.com
Recebido em: 10/06/2020

Revisado em: 07/06/2021

Aprovado em: 28/07/2021 